\title{
Sustenance of Tax Administration by Information and Communications Technology in Nigeria
}

\author{
Oseni, Michael \\ Department of Accountancy \\ The Polytechnic, Ibadan, Nigeria.
}

\begin{abstract}
The focus of this paper rests on the nexus of information and communications technology in administration of tax in Nigeria. Nearly every sector of the national life has been affected by the ICT. ICT has defined the business, social and personal environment of the country. The study used content analysis method to highlight challenges that are peculiar to tax administration in Nigeria. The periods where the rule of the thumbs were used in determining the assessable income of tax payers compared to the recent times where ICT are used in tax administration to near pinpoint accuracy were analysed. With the use of ICT, leakages were reduced. It was found out that there is no hiding place for tax evaders with the use of this modern technology since the all potential taxpayers are captured by the system. Nevertheless the use of ICT can be catastrophic if carelessly employed by both the tax payers and the tax administrators as scammers and hackers of the internet facilities can utilize the ignorance or the lax security of the system.
\end{abstract}

Keywords: e-payment, e-tax, tax payer identification number, agbekoya, opon imo, 'tax officials'

\section{INTRODUCTION}

In discharging its duties to the governed, the government has to use resources from the citizenry and the state in order to provide essential services to the people. These services varied from security and infrastructural development to the welfare of the people. In whatever types of government being practiced, these services are sine qua non to the existence of the government. Socialist, democratic or monarchy types of government are also involved. The major sources of funds used in running the machineries of government are taxes collected by various tiers of government which are mainly direct and indirect taxes (Oseni, 2014a). During the pre-colonial periods and before modern taxation were introduced, traders moving their wares from one region to another were required to pay toll charges on their merchandise. Agricultural produce were also taxed in the development of the land. Large estates left behind by wealthy citizens were also taxed. In fact, taxation itself is as old as human existence (2014, Dike).

Whenever the purse of the town council was lean, the workers in the council would be gathered to participate in an ad hoc assignment. The assignment would be to go for tax defaulters in the areas. Before dawn, these ad hoc staff would require the eligible tax payers in the council's jurisdiction to present their current tax receipts. Those who are unable to present these tax receipts would be arrested and taken to the headquarters of the council where they would be detained for the whole day. In the old Ibadan metropolitan council, these defaulters would be taken to Mapo, the city town hall, where they would be subjected to the inclement weather for the whole day. At the end of the day, those captured or arrested would be released 
and that would be the end of the matter for that day. That does not mean that the raid would not be carried out the next day. The person arrested today may also be arrested the following day. The cat and mouse game would start for those who are unwilling or unable to pay tax to be dodging these 'tax officials' by either changing the routes or going to their activities early in the morning before these 'tax officials' are on the road. In determining those who are qualified to pay these taxes, those who are grown up physically were the main targets. Inability to pay these poll taxes often results to seizure of chattels and other valuables.

Civil unrest in Nigerian towns and villages in 20th century were often attributed to excessive tax assessment of the people. The Aba riot of 1929 and that of Agbekoya riot of 1969 during the Nigerian civil war were typical examples of open resentment by people against the government authorities for excessive taxes (Oseni, 2014a).

Assessable incomes of taxpayers were determined by the rule of the thumb. Financial statements that should be used as basis for computing chargeable tax were inadequate if at all any existed. This then invariably created rooms for sharp practices in the administration of tax which eventually result in low revenues for the government. It is the responsibility of the tax authority to determine the tax payers in its area of jurisdiction. So also a business enterprise is expected to register at the tax office.

The aversion to pay tax by corporate citizens is easily noticeable despite the fact that the laws are clear on amount to be paid as tax. Every taxable person is expected to file in his returns every tax year. Special incentives of $1 \%$ are given to those who render self-assessment returns while those who refused to render returns are assessed on what is known as best of judgment assessment. The tax authority has the prerogative of assessing the tax payer on what it thinks best -but mostly on higher rate. The results of the last financial year are mostly used to determine assessable tax for business enterprise while the current income is used for those in employment. Simply put, businesses are taxed on preceding year basis while incomes from employment are taxed on actual year basis. But not all types of businesses are taxed on preceding year basis. Petroleum profit taxes are on actual basis.

Capital allowances in lieu of depreciation, disallowable expenses, dependents and other allowable expenses like assurance payments are taken into consideration before finally arriving at chargeable profits. If it is employment, the tax payable is supposed to be paid in equal installments throughout the year while business enterprises are expected to pay once the notice of assessment is final and conclusive?

Workers in employment are normally required to file their tax returns at the beginning of the year. They are expected to declare the number of children, dependent relatives they were having during the preceding year which would be used to determine the amount of reliefs to be claimed in the current year. It is also provided to state if the taxpayer is married. The reliefs are limited to four children who are under the age of 18 and unemployed or in full time education or training. The dependents are limited to two but there is no provision for a woman to claim relief for having a husband. Spurious claims are made with the intention of having as much reliefs as possible resulting to lower tax being paid.

For failure to pay tax based on reliefs available or rendering false returns, most tax authorities now give consolidated reliefs to the tax payers. Children, wife and dependent allowances are now grossed up to give a single relief allowance. In government establishments like tertiary 
institutions, taxes are now deducted from employees' salaries before the emoluments after tax are remitted to establishments.

Certain transactions involving government establishments now require showing evidence of payment of taxes as and when due by the presentation of tax clearance certificates showing payments of taxes for the past three years. These certificates are issued by the relevant tax authorities after confirming that taxes due were actually paid and whenever shortfalls were found, the taxpayers would be required to pay additional tax.

The administration of tax now requires competent and effective human resources in order to make sure that all taxes due are collected promptly and correctly. For this reason, it is necessary to professionalize all the tax agencies in the country. The Federal Inland Revenue Service and States Internal Revenue Services are established at the centre and in all the states of the federation respectively. The third tier of government which is the local government councils are statutorily required to have Local Government Revenue Committees.

As taxes are no longer being administered as in those days when the rule of thumb was the order of the day and the services of the governments are more challenging, the use of modern tools in technology is of paramount importance.

What are then the contributions of information communication technology to the administration of tax in Nigeria? Is ICT effective in the administration of tax in Nigeria as in other lands? What are the imminent and peculiar challenges of ICT in the administration of taxes in Nigeria? The main focus of this paper will be finding answers to these questions. The paper will thereafter be divided into four sections. Section two is on conceptual framework and literature review while section three is on model specification and research methodology. Section four is on findings and discussions. Summary, conclusion and recommendation will be in chapter five.

\section{Conceptual Framework}

\section{CONCEPTUAL FRAMEWORK AND LITERATUE REVIEW}

\section{Tax}

A tax is a compulsory financial charge or other levy imposed upon a taxpayer by the government in order to fund various public expenditures for the benefits of the people. Some of these various public expenditures include but are not limited to the cost of providing enforcement of law and public order, economic infrastructure, welfare and public services. State's debts are also paid from the taxes collected. Taxes may be levied by different levels of government or its agents, and the inclusion of "compulsory" serves to remind that evasion is punishable by law. Taxes may be direct and indirect and it may be paid in cash or its labour equivalent. The income of individuals and business entities, including corporations are subject to tax. Tax is generally imposed on net profits from business, net gains and other income. The computation of income subject to tax may be determined under accounting principles and conventions. There are clear jurisdictions in respect of what is collectible by the national government and what is collectible by the local governments. It is the responsibility of the Federal Inland Revenue Service (FIRS) to collect the company income tax while the state governments are responsible for personal income tax. For effective administration, a tax system has to observe the fundamental principles of taxation which are equity, simplicity, economy, and certainty. In order to discharge its duties to the people it governs, a good government in power has to put in place a good system of taxation. The distribution of the tax burden has to be ascertained in respect of who will pay taxes, how much they will pay and how the taxes collected will be spent. Tax imposed may be progressive, regressive or proportional. A progressive tax leads to increased tax rate as the amount of income increases while the 
opposite is the case with the regressive tax. In proportional tax, the effective tax rate is fixed whatever the amount of income.

\section{Information and Communications Technology}

Information and communications technology which is often abbreviated to ICT and sometime called information technology (IT) is the convergence or integration of telecommunications, computers which enable users to access, store, transmit and manipulate information. This involves telephone networks and computer networks. Telecommunications involve the usage of telephone lines and wireless lines.

\section{Self assessment}

In its 2014 Tax Year Planner, The Federal Inland Revenue Service (IFRS) described self assessment as a method in which a taxpayer completes his tax returns forms where his tax liabilities are properly computed and thereafter pay the self assessment tax with supporting documents on or before due date. Voluntary tax compliance is a legal obligation that requires an individual, enterprise, company or institution to register for tax, keep accurate records, disclose business affairs in full, file tax returns and pay tax due on or before due date.

\section{Literature Review}

Efunboade (2014) put forward three areas where the use of Information Communication Technology is being synchronized with the Nigerian tax system. These moving innovations in the use of ICT which has enhanced tax administration include the TIN (Taxpayer Identification Number), Project FACT (Factual Accurate Complete Timely) and ITAS (Integrated System of Tax Administration). The TIN is a computer-generated unique identifier to every taxable person identifier made it possible to drag all taxable Nigerians into the tax net. The FACT is an integrated electronic system of tax registration, tax payment and accounting while ITAS includes, Business Process Reengineering, Systems Development, Change Management and automation of Finance and Accounts Functions such as Tax clearance verification, Tax refund application software and contact management centre. He concluded that these emerging global infrastructures could make it increasingly possible for eligible taxpayers to pay tax online anywhere and anytime.

ICT is not only a useful tool for tax administration, but also useful in international tax differential by choosing the optimal location and form of investment and the risks associated with the business. In regards to business locations, ICT has made it possible to have business units not to be centralized in one country. Schafer and Spengel (2004) are of the opinion that due to the increased use of ICT, geographic distances within a company, between different companies as well as between companies and consumers tend to be less relevant. Besides, firm-specific factors such as intangible assets and services nowadays constitute the main factors for the creation of value. Consequently, many functions of a company are becoming more mobile and more independent of physical location factors. But they argued further that due to the use of ICT, it has now become more and more difficult to identify the source of income, and the source is more often susceptible to manipulation.

The right tools in human resources and equipments are necessary to achieve good results in the administration of taxes in Nigeria. Abiola and Asiweh (2012) are of the opinion that management and organisational approaches in the implementation of tax policy is very weak. And these weaknesses can be traced to the use of poor tools, inadequate staffing of the taxcollecting organisations, poor funding, bad access road to the interior of the rural areas and poor enlightenment. They concluded that what is obtainable in most tax system is paper documentation that have been characterised with mutilation and falsification of figures both 
on the part of the tax officers and the tax payers as well. In highlighting factors that militate people not to pay tax, the poor performance of social amenities like electricity supply have to a large extent discouraged tax payment.

Agusiy (2003) is of the opinion that information technology play vital roles in developing countries where data accuracies are hindrances to effective tax administration. He highlights the benefits to include speed and improved efficiency; accuracy of tax computation; reliability of data used; consistency in the information generated and improved productivity. Information technology is being applied in intelligence gathering, the issue of unique tax identification number and the use of electronic payment (e-payment).

Virtually all aspects of life have been taken over by Information Communication Technology. Governance, health, banking, oil and gas are enjoying tremendous sustenance by the modern phenomenon. The Bank Verification Number (BVN), Permanent Voter's card, card reader, biometric driving license, national identity card etc are some of the beneficiaries. Even Osun state has adopted the Opon Imo (Table of Knowledge) to students in its tertiary institutions (Business Day, 2015).

The ICT revolution came to Sub-Saharan Africa when countries in other continents had got their fair bites. The local internet access was only available in few African countries some years ago. But ever since, the use of the technology is on the increase enabling countries to depend on public and commercial internet access points. The rudimentary access points like the cybercafé exploit the dearth and infancy of the industry to exploit the opportunity by charging fees for their services (Longe, Ngwa, Wada, Mbarika and Kvasny, 2009). The fundamental problems of erratic power supply and inadequate telecommunication infrastructure has hindered the continent from uninterrupted access to innovative information technology applications such as e-government, e-commerce, telemedicine, teleconferencing and teledemocracy. So also access to ICT has also provided a platform for a criminal invasion and a spree of cyber abuses (Longe et al., 2009).

Provision of good governance is the major role of government. This is enshrined in the 1999 Nigerian constitution where it was expressly stated that the role of the government is the provision of security and welfare to the people. Therefore, the provision of electricity, potable water, good roads, telecommunications, etc to the general public by government is part of good governance. Where government does not provide these facilities to citizens in exchange for taxes paid, citizens become reluctant to pay taxes. As Akpo (2009) points out, the administration of taxes are bound to have challenges. And these challenges highlighted are economic, environmental, educational, structural, political, social, constitutional, cultural and religious. All these are interwoven and each one is as important as the other. In order to attain effective tax payment, he concludes that a comprehensive approach is needed to tackle these identified challenges.

Taxation is the imposition by government of compulsory contributions or levies on the citizens, property, income, commodities, transactions and so forth, for the purpose of raising revenue for government expenditure. Chatama (2013) in his studies on the impact of ICT on taxation in Tanzania concluded that application of ICT affected both the design and administration of tax system. It has also helped to maintain consistent record keeping; timely access to such records and fast processing of return which together improved the performance of tax revenue.

In their submission on the efficiency gains from dynamic tax reforms, Auerlach, Kotlikoff and Skinner (1981) concluded that a switch to consumption taxation generates a sustainable 
welfare gain of almost 2 percent of lifetime resources while a transition to wage taxation generates a loss of greater than 2 percent of lifetime resources. The taxation dependence in Nigeria is skewed to production tax in form of petroleum tax which heavily financed Nigeria's recurrent and capital budget.

Business activities and the way people live and work had been changed by the adoption of Information and Communication Technology (ICT). Medium and large firms used the computers and internet facilities more than the small firms that cannot afford the high cost of equipments coupled with limited knowledge and skills in computer technology and their responsiveness to taxation (Ssewanyana and Busler, 2007).

In highlighting the external factors that militated against the smooth operation of tax administration in Tanzania, Kitillya (2011) mentioned poor ICT Backbone as one of the external factors beyond the control of Tanzania Revenue Authority. It may not be for the country alone but all developing countries may suffer the same.

\section{Technique of Analysis}

\section{RESEARCH METHODOLOGY}

For the purpose of this paper, secondary data were used. Relevant materials such as textbooks, Journals, Newspaper and other official documents of Federal Inland Revenue Service (FIRS) both in prints and electronics were widely consulted. Available literature on entrepreneurship and its effects on Nigerian economy were incorporated into this study.

\section{FINDINGS AND DISCUSSIONS}

At its 2015 budget defense before the Senate Committee on Drugs, Narcotics, Financial Crimes and Anti-Corruption, the chairman of ICPC Mr. Ekpo Nta said that out of 156 contractors with the Federal Ministry of Works, 50 of them operated with forged tax certificates. This shows how really bad things are in the system. If $32 \%$ forgery could be detected in one agency, it is better imagined how the rot would have permeated the whole system in the country. What would be the result of this forgery? Government is denied revenue and this affect the development that would have had permanent effects on the lives of the people (Vanguard Editorial, 2015).

The mission of Japan's National Tax Agency is to "Help taxpayers properly and smoothly fulfill their tax duties." In order to fulfill this, various measures including online national tax return filing and tax payment system (e-Tax) were introduced using the ICT. With additional publicity and briefings more taxpayers are using ICT to file their tax returns. In a period of four years, the National Tax Agency, Japan reported that the users of ICT in tax related issues increased 1.4 times (National Tax Agency, 2013).

The electronic processing of tax collections which include accuracy and promptness was noticeable in Tanzania between 1996 and 2007. A remarkable increase was recorded by virtue of using ICT in processing tax. According to Chatama (2013), iTAX contributed to improved revenue by increasing tax collected from US $\$ 25$ million per month in 1996 to US\$300 million per month in 2007.

The new innovation for payment of tax online introduced by the Federal Inland Revenue Service (FIRS) is worthwhile. According to the representative of the acting chairman of the board, the e-payment would not only boost tax revenue collection but also strengthen the selfassessment regime and improve voluntary tax compliance using the online payment options. It 
would greatly reduce time and cost of compliance for tax payers as well as easing the interface between taxpayers and authorities. The new system would not only ease compliance for the taxpayers, but also enable FIRS to ensure greater transparency in tax operations (Mashi, 2015) From time immemorial, the payments of taxes - be corporate or personal are often not rigidly implemented by the taxpayers. Payments of taxes, if the system allows it are often neglected by the taxpayers. Effective collections of taxes are the responsibilities of the tax authorities and this in most cases require the experience and human resources. The ICT has now made it easier to administer tax computation and payment. Tax identification numbers are now issued to all the tax payers and every tax payer can be tracked down in respect of his tax responsibilities at any time of the year. Taxpayers are now being reminded electronically when tax is due. Motor licensing authorities now send short message reminders to owners of vehicles shortly before their vehicle particulars are due for renewal.

The speed and accuracy which lead to optimum efficiency in Information Communication Technology can be abused if not properly managed. The online payment of taxes can be short circuited if not properly managed. This can lead to cybercrimes of various proportions. Taxpayers are warned through advertisements in order not to fall victims of the scammers. They are advised not to respond to any email or short messages (sms) purportedly from FIRS requesting you to remit your taxes online and all tax payment transactions should be made only to designated banks and collection of e-receipts should be made thereafter. In addition, public computer should not be used for private banking transactions (Businessday, 2014).

But with the introduction of ICT to the tax administration of Lagos state, the internally generated revenue has improved. The automation of records and taxpayers had helped to boost the revenue of the state and the employees in the state revenue service are easily tracked (Businessday, 2015).

\section{SUMMARY, CONCLUSIONS AND RECOMMENDATION}

The use of ICT in tax administration was the focus of this paper. The old method of the rule of thumb compared to the modern tools being used to assess taxable income was discussed.

The ICT has brought many innovations to the administration of tax and this has invariably increased the net revenue collected. There seems to be no hiding place for tax evaders with the use of the modern tools. Continuous training of employees should be encouraged so as to meet challenges created by the systems.

The users i.e. the taxpayers are to be aware of the scams that are prevalent in the use of internet especially the payment of tax online.

Responsible corporate citizens should be encouraged and tax evaders should have their names published every year by the relevant tax authorities to serve as deterrent to others. So also, responsible corporate citizens who pay their taxes as and when due should be appreciated

\section{References}

Abiola, J and Asiweh, M (2012) Impact of Tax Administration on Government Revenue in a Developing Economy A Case Study of Nigeria International Journal of Business and Social Science Vol. 3 No. 8 [Special Issue - April 2012] 99

Agusiy, B. A. (2003) Effects of Information Technology on the efficiency of Tax Administration in Nigeria (A case study of Enugu State Board of Internal Revenue) An unpublished project for the award of BSc. (Accounting) by Caritas University, Amorji-Nike Enugu, Enugu State, Nigeria, pp 65-67. 
Akpo, U. (2009) the people as government: Imperatives of tax payment. Paper presented at 1st Akwa Ibom State Revenue Submit April 6 \& 7, 2009

Alan J., Auerlach, A.J., Kotlikoff, L.J and Skinner, J (1981) the efficiency gains from dynamic tax reform, Working Paper No. 819 National Bureau of Economic Research, 1050 Massachusetts Avenue, Cambridge MA 02138 December 1981

Businessday, (2014) Don't fall victim to online Tax Fraudsters Protect yourself, Being Federal Inland Revenue Service (FIRS) advertisement, Businessday Newspaper, May 16 p15.

Businessday,(2015) Boosting ICT's contribution to economic growth. Businessday Editorial May 4, 2015 p12

Businessday, (2015) Sustaining development in the ICT sector. Businessday Editorial December 8, 2015 p12

Chatama, Y. J. (2013) The impact of ICT on Taxation: the case of Large Taxpayer Department of Tanzania Revenue Authority/, Developing Country Studies, ISSN 2224-607X (Paper) ISSN 2225-0565 (Online) Vol.3, No.2, 2013 www.iiste.org

Dike, M. A, (2014) Taxation is as old as human existence, Businessday Thursday22, May 2014 Being Interview granted by President of Chartered Institute of Chartered Taxation of Nigeria.

Efunboade, A. O. (2014) Impact of ICT on Tax Administration in Nigeria Computer Engineering and Intelligent Systems ISSN 2222-1719 (Paper) ISSN 2222-2863 (Online) Vol.5, No.8, 2014 www.iiste.org

Kitillya, H. M. (2011) Tax Administration Reforms in Tanzania - Experience and Challenges, Being paper presented to the Conference on Revenue Mobilisation in Developing Countries, IMF - Fiscal Affairs Department Washington D.C. April 17-19, 2011 Retrieved from on Friday? March 3, 2015

Longe, O., Ngwa, O., Wada, F., Mbarika, V and Kvasny. L (2009) Criminal Uses of Information \& Communication Technologies in Sub-Saharan Africa: Trends, Concerns and Perspectives Journal of Information Technology Impact Vol. 9, No. 3, pp. 155-172, 2009

Mashi, K. (2015) Nigerians can now pay their taxes online Retrieved from www.mynewswatchtimesng.com/Nigerians -can-now-pay-their-taxes-online/ on Tuesday May 5, 2015.

National Tax Agency, Japan, National Tax Agency Report 2013 http:// www.nta.go.jp

Oseni, M. (2014a) Multiple Taxation as a Bane of Business Development in Nigeria, Academic Journal of Interdisciplinary Studies MCSER Publishing, Rome-Italy Vol. 3 No 1 March 2014 E-ISSN 2281-4612 ISSN 22813993 www.mscer.org

Schafer, A and Spengel, C (2004) International Tax Planning in the Age of ICT, ZEW (Centre for European Economic Research)Discussion Paper No. 04-27 ftp://ftp.zew.de/pub/zew-docs/dp/dp0427.pdf

Ssewanyana, J and Busler, M (2007) Adoption and usage of ICT in developing countries: Case of Ugandan firms International Journal of Education and Development using Information and Communication Technology (IJEDICT), 2007, Vol. 3, Issue 3, pp. 49-59.

Vanguard, (2015) ICPC's Partial Shocks, the Vanguard Newspaper Editorial, March 4, 2015

Weick, T. (2014) Nigeria needs efficient ICT platform to sustain GDP growth. The Sun Newspaper, July 31, pp 8 